\title{
PROXIMATE COMPOSITION, AMINO ACIDS AND FATTY ACIDS PROFILES OF WILD AND CULTURED CLIMBING PERCH, ANABAS TESTUDINEUS (BLOCH, 1795)
}

\author{
Mst Taslima Akter, Md. Hasan Faruque, Md. Rakibul Hasan ${ }^{1}$ and Mohammad \\ Shamsur Rahman* \\ Department of Fisheries, Faculty of Biological Sciences, University of Dhaka \\ Dhaka-1000, Bangladesh
}

\begin{abstract}
The availability and compositions of foods in the aquatic system have a direct influence on nutritional compositions of fish muscle. This research aimed to determine the nutritional compositions of wild and cultured climbing perch, Anabas testudineus, between pre-monsoon and post-monsoon. The proximate compositions, total amino acid, and fatty acid profiles were determined by AOAC, HPLC and GC, respectively. The results in dicated that proximate (e.g., moisture, ash, protein and lipid), amino acid and fatty acid profile varied significantly $(p<0.05)$ between wild and cultured fishes depend on season. The highest amount of moisture $(79.62 \pm 0.92 \%)$ was found in wild A. testudineus and lowest amount of ash $(2.50 \pm 0.09 \%)$ was found in cultured $A$. testudineus during pre-monsoon. For both cultured and wild $A$. testudineus, amount of protein was higher in postmonsoon than in pre-monsoon period. The protein and amino acids contents as well as lipid and fatty acids of the fish species showed a significant $(p<0.05)$ seasonal variations. Among the 14 recorded amino acidsthe major amino acids in the total crude protein were histidine, methionine, isoleucine, lysine, glutamic acid, and glycine. The ratio of Essential Amino Acid (EA)/Non-Essential Amino Acid (NEA) was highest (0.34) in cultured fish of post-monsoon season and lowest (0.25) in wild fish of pre-monsoon season. The major fatty acid so wild and cultured A. testudineus were oleic acid (18:1), palmitic acid (16:0), linoleic acid (18:2), stearic acid (18:0), palmitoleic acid (16:1), andmyristic acid (14:0). Some fatty acids [Lauric acid (C12:0), Pentad cyclic acid (C15:0), Arachidic acid (C20:0)]were not detected in cultured fish but present in wild fish. The $n-3 / n-6$ ratio was highest $(0.48)$ in wild fish of post-monsoon season and lowest $(0.14)$ in cultured fish of pre-monsoon season. Therefore, a comprehensive study on wild and cultured climbing perch is required for further confirmation of the result of the present study.
\end{abstract}

Key words: Seasonal variation, Nutritional compositions, Amino acid ratio, n$3 / \mathrm{n}-6$ ratio, Climbing perch

\section{INTRODUCTION}

Fish is an animal-source food comprising about $60 \%$ of protein intake in the diet of millions of Bangladeshi peoples at the rate of $18.1 \mathrm{~kg}$ per person per

\footnotetext{
*Author for corresponding: <shamsur@du.ac.bd>, ${ }^{1}$ Zoology Section, Biological Research Division, Bangladesh Council for Scientific and Industrial Research (BCSIR), Dhaka 1000, Bangladesh. (c)2020 Zoological Society of Bangladesh DOI: https://doi.org/10.3329/bjz.v48i2.52376
} 
year (Belton et al., 2014). Fisheries and aquaculture plays an imperative role in Bangladesh economy as it strengthens food security, reduces poverty, and promotes employment and foreign trade opportunities. Bangladesh currently ranks $3^{\text {rd }}$ in inland fishing production and $5^{\text {th }}$ in aquaculture production worldwide(FAO, 2018). Inland fish farming of native and exotic carp species, especially Pangas, Tilapia, Thai/VietnamiKoi has increased significantly in the last two decades. Furthermore, there has also been an increasing interest in aquaculture focusing the small indigenous fish species like Gulsha, Koi, Magur, Mola, Pabda etc. since these species have a high consumer demand and have a greater contribution to the nutrition supply at household level (FRSS, 2015). The contribution of the Anabas testudineus, commonly known as 'Koi' in Bengali and climbing perch in English (both the indigenous and Thai/Vietnam variety) to the national fish production is about $4-5 \%$ (DoF, 2015). Now-a-days commercial Koi fish farming in pond is prevalent to meet increasing demand. Koi farming is very easy and profitable because of its commercial and nutritional importance.

The most edible part of fish is muscle that contains protein, lipid, carbohydrate, moisture, ash, minerals etc. The main constituent of fish flesh is moisture (about 80 per cent) (Murra and Burt, 2001).Fish is typically an ideal source of protein owing to amino acid composition and digestibility. The protein in the fish flesh ranges between 15-20\% (Murraand Burt, 2001).Fat content of fish varies with the species, feeding, size, age, season, physiological status and geographical location (Exler, 1975).

Amino acids are the chemical substances that make up protein. There are about twenty types of essential and non-essential amino acids. The essential amino acids cannot be synthesized by human body and it must take from the diet. Fish protein is an excellent source of these amino acids, especially lysine and methionine, in contrast to cereal and meat proteins. Fatty acid is a carboxylic acid that is either saturated or unsaturated and has a long aliphatic chain. Fatty acids are considered as the essential sources of fuel because they produce significant amounts of ATP (adenosine triphosphate) when metabolized.

The inter specific and intraspecific differences in the composition of nutrients in fish are likely caused by intrinsic biological factors (e.g., age, size, sex) coupled with some endogenous (e.g., composition of feed) and exogenous drivers (e.g., environment, seasons, salinity) (Huss, 1995; Celik et al., 2005; Li et al., 2011). Body constituents and energy resources may considerably be varied with seasonal life cycles (Puwastien et al., 1999).

However, external feeding is less likely to affect flesh protein contents because protein contents in fish muscle rely primarily on the culture 
environment, species of fish, and the size of the individual (Shearer, 1994). While the cultured fish are supplied with nutrient-rich supplementary feeds; however, it is commonly perceived that the acceptability of fish captured from wild is considered to be greater than that of farmed fish. In contrast, wild fish, may rely fully on natural foods for their sustenance.

A good number of works has already been done on proximate composition of different freshwater and marine fishes (Mazumder et al., 2008, Hossain et al., 2015). Moreover, Onyia et al. (2013) made a thorough study on a variation on proximate composition depending on cultured environments. Yeganeh et al. (2012), Hassan et al. (2010) worked on amino acid and fatty acid profiles and their distribution among fish living in different habitat. Both the aquatic environment and seasons have a substantial influence on the nutrients profile in fish muscle. However, previous studies have focused either of culture environment or seasons to elucidate the variations in nutritional compositions of fishes.

Therefore, this study was designed to determine seasonal variations of the proximate, amino acid and fatty acid profile of cultured and wild climbing perch, Anabas testudineus.

\section{MATERIAL AND METHODS}

Sampling: Wild Koi fish was collected from Jhapabaor $\left(22^{\circ} 59^{\prime} 1.34^{\prime \prime}\right.$, $89^{\circ}$ 9'36.39"E) and the cultured Koi (Thai koi) fish was collected from Matri Fish Hatchery and Integrated Farm, Monirampur, Jessore, Bangladesh in two seasons; pre-monsoon (March-May, 2015) and post-monsoon (SeptemberNovember, 2015). The biometric data of wild and cultured A. testudineus are provided in the Table 1 . For the wild $A$. testudineus, total length was $8.72 \pm 1.08$ $\mathrm{cm}$, and total weight was $25.11 \pm 2.87 \mathrm{~g}(\mathrm{n}=10)$ in pre-monsoon, whereas $11.99 \pm 1.38 \mathrm{~cm}$ and $30.00 \pm 2.18 \mathrm{~g}$ in post-monsoon, respectively. In case of cultured $A$. testudineus, total length was $9.25 \pm 0.93 \mathrm{~cm}$, and total weight was $38.21 \pm 3.06 \mathrm{~g}$ in pre-monsoon time, whereas $10.49 \pm 1.91 \mathrm{~cm}$ and $47.90 \pm 4.62 \mathrm{~g}$ $(n=10)$ in the post-monsoon period, respectively. The collected samples were transported to laboratory by insulated ice box and refrigerated until analysis.

Sample preparation and determination of nutritional compositions: After biometric measurements, fish specimens $(n=10)$ were decapitated, eviscerated, and filleted. The fish muscle was then taken $3-5 \mathrm{~g}$ in triplicate to determine proximate composition. For amino acid and fatty acid analysis, fish muscle was taken from each sample to make a homogenized pooled sample. From pooled sample final analysis of amino acid and fatty acid were done in triplicate. The 
moisture, ash, crude protein content of sampled fish were determined byoven drying method), gravimetric method, and Micro-Kjeldhal method, respectively

Table 1: Biometric data of wild and cultured $A$. testudineus used in this study $(n=10)$

\begin{tabular}{lllll}
\hline & Pre-monsoon & \multicolumn{2}{l}{ Post-monsoon } \\
\hline & Wild & Cultured & Wild & Cultured \\
Total & & & & \\
Length $(\mathrm{cm})$ & & & & \\
Mean $( \pm \mathrm{SD})$ & $8.72 \pm 1.08$ & $9.25 \pm 0.93$ & $11.99 \pm 1.38$ & $10.49 \pm 1.91$ \\
Maximum & 10.30 & 10.60 & 13.80 & 13.80 \\
Minimum & 7.10 & 7.80 & 9.80 & 7.10 \\
Weight $(\mathrm{g})$ & & & & $47.90 \pm 4.62$ \\
Mean $( \pm \mathrm{SD})$ & $25.11 \pm 2.87$ & $38.21 \pm 3.06$ & $30.00 \pm 2.18$ & 52.84 \\
Maximum & 28.84 & 42.76 & 2.61 & 41.56 \\
Minimum & 20.31 & 33.81 & 26.82 & \\
\hline
\end{tabular}

(AOAC, 1995).The lipid content was determined by Folch\& Stanly method (1957). Amino acid profile and fatty acid profile were done by High Performance Liquid Chromatography (HPLC) (Anonymous, 1993) and Gas Chromatographic (GC) analysis (Nichols et al., 1993), respectively.

Statistical analysis: Statistical analysis was performed with the Statistical Package for the Social Sciences (SPSS) v. 20.0 (SPSS, SAS Institute Inc. Gary, USA) and Microsoft office excel 2007. Multiple comparisons were done with Tukey HSD test with one way ANOVA (Analysis of Variance) at 5\% level of significance. The descriptive statistics such as mean, standard deviation (SD), maximum and minimum values were used to represent our findings.

\section{RESULTS AND DISCUSSION}

A comparative analysis was performed to determine the moisture, ash, protein, lipid, amino acid, and fatty acid profile in wild and cultured climbing perch of Jashore district, Bangladesh. Base on the season, the findings revealed a wide variation in the nutritional compositions in terms of proximate, amino acid, and fatty acid contents of wild and cultured Koi fish.

Proximate Composition: Moisture content in our analysis, seasonal variation was observed in moisture content of both wild and cultured Koi fish. Moisture content (Mean \pm SD) of the wild A. testudineus was $79.62 \pm 0.29 \%$ and $75.27 \pm 0.15 \%$ between pre-monsoon and post-monsoon whereas in cultured fish the amount was $74.04 \pm 0.57 \%$ and $73.91 \pm 0.49 \%$, respectively (Table 2). Result also represented that moisture content differed significantly $(p<0.05)$ in both season between wild and cultured Koi fish. Wild fish contained higher amount of moisture $(79.62 \pm 0.92 \%)$ than cultured fish $(73.91 \pm 0.49 \%)$ (Table 2$)$. The highest 
amount of moisture $(79.62 \pm 0.92 \%)$ was reported in wild fish during premonsoon.

Ash content: In pre-monsoon, it was found that the wild and cultured Koi contained $3.62 \pm 0.05 \%$ and $2.50 \pm 0.09 \%$ ash, respectively; on the contrary, in post-monsoon, the amount was $3.02 \pm 0.04 \%$ and $2.90 \pm 0.03 \%$, respectively (Table $2)$. Our finding revealed that a significant difference was observed $(p<0.05)$ in both season (pre-monsoon and post-monsoon) between wild and cultured $A$. testudineus. Wild fish contained higher amount of ash when compared with cultured fish in both seasons.

Crude protein content: Crude protein content of wild Koi in pre-monsoon and post-monsoon was found to $12.13 \pm 0.04 \%$ and $14.74 \pm 0.05 \%$,respectively (Table 2). On the other hand, cultured fish contained $16.04 \pm 0.07 \%$ of crude protein in pre-monsoon and $17.92 \pm 0.05 \%$ in the post-monsoon period. The highest value was recorded in post-monsoon cultured fish $(17.92 \pm 0.05 \%)$ and the lowest value in wild fish $(12.13 \pm 0.04 \%)$ of pre-monsoon. Result of crude protein content stated that significant difference $(p<0.05)$ remains in wild and cultured fish of both seasons.

Lipid content: Lipid content showed variation between pre-monsoon and post-monsoon (Table 2). In pre-monsoon, lipid content was $3.82 \pm 0.07 \%$ and $5.14 \pm 0.02 \%$ in wild and cultured fish, respectively; on the contrary, in postmonsoon the amount were $3.61 \pm 0.06 \%$ and $5.56 \pm 0.03 \%$ in wild and cultured fish, respectively. Significant difference $(p<0.05)$ was found in wild and cultured fish of both season. Total amount of lipid is higher in cultured fish than wild.

Table 2: Seasonal variation in proximate composition (\%) of wild and cultured $A$. testudineus

\begin{tabular}{lllll}
\hline \multirow{2}{*}{$\begin{array}{c}\text { Proximate } \\
\text { composition } \\
(\%)\end{array}$} & \multicolumn{2}{c}{ Pre-monsoon } & \multicolumn{2}{c}{ Post-monsoon } \\
\cline { 2 - 5 } & \multicolumn{1}{c}{ Wild } & \multicolumn{1}{c}{ Cultured } & Wild & Cultured \\
\hline Moisture & $79.62 \pm 0.92^{\mathrm{a}}$ & $74.04 \pm 0.57^{\mathrm{cd}}$ & $75.27 \pm 0.15^{\mathrm{b}}$ & $73.91 \pm 0.49^{\mathrm{d}}$ \\
Ash & $3.62 \pm 0.05^{\mathrm{a}}$ & $2.50 \pm 0.09^{\mathrm{c}}$ & $3.02 \pm 0.04^{\mathrm{b}}$ & $2.90 \pm 0.11^{\mathrm{d}}$ \\
Protein & $12.13 \pm 0.04^{\mathrm{a}}$ & $16.04 \pm 0.07^{\mathrm{c}}$ & $14.74 \pm 0.05^{\mathrm{b}}$ & $17.92 \pm 0.05^{\mathrm{d}}$ \\
Lipid & $3.82 \pm 0.07^{\mathrm{a}}$ & $5.14 \pm 0.02^{\mathrm{c}}$ & $3.61 \pm 0.06^{\mathrm{b}}$ & $5.56 \pm 0.03^{\mathrm{d}}$ \\
\hline
\end{tabular}

Data are expressed as mean \pm SD. Mean values followed by different letters within a row denote significant differences $(p<0.05)$.

FAO (1991) stated that fish typically contains $72 \%$ water, $19 \%$ protein, $8 \%$ fat, $0.5 \%$ calcium, $0.25 \%$ phosphorus and $0.1 \%$ vitamin $\mathrm{A}, \mathrm{D}, \mathrm{B}$ etc. The percentage of proximate composition showed a wide variation in wild and cultured fish. Alemu et al. (2013) showed that both exogenous and endogenous factors influence fish body composition. 
In general, moisture content range fall between $60-80 \%$ in many fish (Murra and Burt, 2001). In our study, seasonal variation was observed in moisture content of wild and cultured fish. The moisture content varied from73.06-80.62\%. The highest value was found in wild Koi fish during premonsoon, $79.62 \pm 0.29 \%$, and the lowest value was in cultured fish during postmonsoon season $73.91 \pm 0.16 \%$. Hossain et al. (2015) analyzed proximate composition of A. testudineus collected from fish market. They found $72.60 \pm 0.17 \%$ moisture in Koi fish.

Ash content was found to vary from 2.37 to $3.71 \%$. In pre-monsoon, wild and cultured fish illustrated that they contained $3.62 \pm 0.02 \%$ and $2.50 \pm 0.03 \%$ ash, respectively; on the contrary, in post-monsoon, the amounts were $3.02 \pm 0.01 \%$ and $2.90 \pm 0.03 \%$, respectively. Hossain et al. (2015) described that A. testudineus contained $3.02 \pm 1.12 \%$ ash.

The protein in the fish flesh ranges between 15-20\% (Murraand Burt, 2001). Hossain et al., (2015) described that A. testudineus contained $16.18 \pm 0.13 \%$ protein. The present study coincides with the work. Lipid content ranged from 3.56 to $5.61 \%$ in pre-monsoon and post-monsoon. Similar result was shown that $A$. contained $5.31 \pm 0.37 \%$ lipid (Hossain et al., 2015).

Amino Acids Profile: Amount of amino acid in protein varied seasonally in both wild and cultured fish (Table 3).A total of 14 amino acids-six essential amino acids (EAs) and eight non-essential amino acids (NEAs) - were found in the present study. EAs that were present include threonine, valine, methionine, isoleucine, leucine and lysine; and NEAsinclude aspartic acid, serine, glutamic acid, glycine, alanine, histidine, tyrosine, and arginine.

Threonine: In pre-monsoon, amount of threonine was $0.277 \pm 0.006 \%$ and $0.437 \pm 0.006 \%$ in wild and cultured fish, respectively; on the contrary, in postmonsoon, the amount was $0.320 \pm 0.02 \%$ and $0.460 \pm 0.04 \%$, respectively. Significant difference $(p<0.05)$ resides in wild and cultured fish of both seasons; but irrespective of the season, no such significant difference $(p>0.05)$ was found within the wild and cultured Koi.

Valine: Content of valine in wild A. testudineus in pre-monsoon and postmonsoon were $0.090 \pm 0.02 \%$ and $0.100 \pm 0.01 \%$, respectively. On the other hand, cultured fish contains $0.110 \pm 0.017 \%$ and $0.140 \pm 0.03 \%$ valine in pre-monsoon and post-monsoon, respectively. The highest value was recorded in cultured fish duringpost-monsoon and the lowest value in wild fish during pre-monsoon. The amount of valine content did not varied significantly $(p>0.05)$ between seasons and habitats.

Methionine: Amount of methionine in wild fish was $0.313 \pm 0.029 \%$ and $0.35 \pm 0.02 \%$ in pre-monsoon and post-monsoon whereas in cultured fish the 
amount was $0.457 \pm 0.023 \%$ and $0.490 \pm 0.03 \%$,respectively. Significant difference was observed $(p<0.05)$ between wild and cultured $A$. testudineus of both seasons but no significant variation $(p>0.05)$ in both wild and cultured fishes between seasons.

Isoleucine: Isoleucine content of the wild A. testudineus was $0.527 \pm 0.032 \%$ and $0.620 \pm 0.04 \%$ in pre-monsoon and post-monsoon season whereas in cultured fish the amounts were $0.8433 \pm 0.05 \%$ and $0.907 \pm 0.035 \%$, respectively. The mean values of isoleucine content varied significantly $(p<0.05)$ between wild and cultured fish of both seasons.

Leucine: In pre-monsoon, wild and cultured fish contained $0.133 \pm 0.021 \%$ and $0.170 \pm 0.02 \%$ leucine, respectively; on the contrary, in post-monsoon, the amount were $0.170 \pm 0.017 \%$ and $0.210 \pm 0.01 \%$, respectively. The values of leucine content differ significantly between the wild Koi of pre-monsoon and culture Koi of post-monsoon season.

Lysine: In pre-monsoon, wild and cultured Koi fish contained $0.300 \pm 0.026 \%$ and $0.367 \pm 0.012 \%$ lysine, respectively; and in post-monsoon, the amount was $0.370 \pm 0.02 \%$ and $0.440 \pm 0.03 \%$. The variation in lysine content between the wild and cultured Koi fish of both seasons was statistically significant $(p<0.05)$.

Asparticacid: In pre-monsoon, amount of aspartic acid in wild and cultured fish was $0.737 \pm 0.012 \%$ and $0.890 \pm 0.017 \%$ whereas in post-monsoon the amount was $0.760 \pm 0.03 \%$ and $0.930 \pm 0.01 \%$, respectively. A significant variation in aspartic acid content was observed $(p<0.05)$ among wild and cultured fish of both seasons

Serine: Cultured koi fish contained $0.463 \pm 0.006 \%$ and $0.490 \pm 0.01 \%$ serine in pre-monsoon and post-monsoon whereas in case of wild fish the amounts were $0.323 \pm 0.015 \%$ and $0.360 \pm 0.04 \%$, respectively. Likewise aspartic acid, the amount of serine varied significantly between wild and cultured fish of both seasons.

Glutamic Acid: In pre-monsoon, amount of glutamic acid was $0.990 \pm 0.026 \%$ and $1.147 \pm 0.025 \%$ in wild and cultured Koi, respectively. On the other hand, in post monsoon, the amount were $1.040 \pm 0.04 \%$ and $1.260 \pm 0.03 \%$, respectively. Glutamic acid contents varied significantly $(p<0.05)$ between the culture fish of pre-monsoon and post-monsoon; however, no such variation was found in wild fish of both seasons. Glycine: Amounts of glycine in wild fishes in pre-monsoon and post-monsoon were $1.290 \pm 0.026 \%$ and $1.380 \pm 0.02 \%$, respectively. Moreover, cultured fish contained $1.450 \pm 0.02 \%$ glycine in premonsoon and $1.580 \pm 0.03 \%$ in post-monsoon. Result represented that glycine content differed significantly $(p<0.05)$ in both seasons between wild and cultured Koi fish. 
Alanine: Amount of alanine in wild Koi fish were $0.397 \pm 0.012 \%$ and $0.420 \pm 0.017 \%$ during pre-monsoon and post-monsoon, respectively. On the contrary, the amounts were $0.490 \pm 0.01 \%$ and $0.550 \pm 0.029 \%$ in cultured Koi fish, respectively. The highest value was recorded in post-monsoon cultured fish, and the lowest value in wild fish of pre-monsoon and significant difference $(p<0.05)$ was found between cultured and wild Koi of both seasons.

Histidine: Cultured fish contained $1.823 \pm 0.025 \%$ and $1.870 \pm 0.01 \%$ histidine in pre-monsoon and post-monsoon, whereas in the case of wild fish the amount was $2.023 \pm 0.084 \%$ and $2.240 \pm 0.02 \%$, respectively. Significant difference was observed $(p<0.05)$ between cultured fish of both seasons.

Tyrosine: In pre-monsoon, wild and cultured Koi fish contained $0.383 \pm 0.015 \%$ and $0.473 \pm 0.012 \%$ tyrosine, respectively; on the contrary, in post-monsoon, the amount was $0.440 \pm 0.02 \%$ and $0.55 \pm 0.04 \%$, respectively. No significant difference $(p>0.05)$ lies between wild fish but cultured Koi fish exhibited significant difference $(p<0.05)$.

Arginine: Arginine content of the wild A. testudineuswere $0.407 \pm 0.015 \%$ and $0.47 \pm 0.01 \%$ in pre-monsoon and post-monsoon seasons whereas in cultured fish, the amounts were $0.52 \pm 0.026 \%$ and $0.58 \pm 0.04 \%$, respectively.

Table: 3 Amino Acids composition (\%) of wild and cultured A. testudineus

\begin{tabular}{lcccc}
\hline \multirow{2}{*}{ Amino Acids } & \multicolumn{2}{c}{ Pre-monsoon } & \multicolumn{2}{c}{ Post-monsoon } \\
\cline { 2 - 5 } & Wild & Cultured & Wild & Cultured \\
\hline Essential amino acids (EAs) & & & \\
Threonine & $0.277 \pm 0.006^{\mathrm{a}}$ & $0.437 \pm 0.006^{\mathrm{b}}$ & $0.320 \pm 0.020^{\mathrm{a}}$ & $0.460 \pm 0.040^{\mathrm{b}}$ \\
Valine & $0.090 \pm 0.020^{\mathrm{a}}$ & $0.110 \pm 0.017^{\mathrm{a}}$ & $0.100 \pm 0.010^{\mathrm{a}}$ & $0.140 \pm 0.030^{\mathrm{a}}$ \\
Methionine & $0.313 \pm 0.029^{\mathrm{a}}$ & $0.457 \pm 0.023^{\mathrm{b}}$ & $0.350 \pm 0.020^{\mathrm{a}}$ & $0.490 \pm 0.030^{\mathrm{b}}$ \\
Isoleucine & $0.527 \pm 0.032^{\mathrm{a}}$ & $0.8433 \pm 0.050^{\mathrm{b}}$ & $0.620 \pm 0.040^{\mathrm{a}}$ & $0.907 \pm 0.035^{\mathrm{b}}$ \\
Leucine & $0.133 \pm 0.021^{\mathrm{a}}$ & $0.170 \pm 0.017^{\mathrm{ab}}$ & $0.170 \pm 0.020^{\mathrm{ab}}$ & $0.210 \pm 0.010^{\mathrm{b}}$ \\
Lysine & $0.300 \pm 0.026^{\mathrm{a}}$ & $0.367 \pm 0.012^{\mathrm{b}}$ & $0.370 \pm 0.020^{\mathrm{b}}$ & $0.440 \pm 0.030^{\mathrm{c}}$ \\
Non-essential amino acids (NEAs) & & & \\
Aspartic Acid & $0.737 \pm 0.012^{\mathrm{a}}$ & $0.890 \pm 0.017^{\mathrm{b}}$ & $0.760 \pm 0.030^{\mathrm{a}}$ & $0.930 \pm 0.010^{\mathrm{b}}$ \\
Serine & $0.323 \pm 0.015^{\mathrm{a}}$ & $0.463 \pm 0.006^{\mathrm{b}}$ & $0.360 \pm 0.040^{\mathrm{a}}$ & $0.490 \pm 0.010^{\mathrm{b}}$ \\
Glutamic & $0.990 \pm 0.026^{\mathrm{a}}$ & $1.147 \pm 0.025^{\mathrm{b}}$ & $1.040 \pm 0.040^{\mathrm{a}}$ & $1.260 \pm 0.030^{\mathrm{c}}$ \\
Acid & \multicolumn{3}{c}{} & \\
Glycine & $1.290 \pm 0.026^{\mathrm{a}}$ & $1.450 \pm 0.020^{\mathrm{c}}$ & $1.380 \pm 0.020^{\mathrm{b}}$ & $1.580 \pm 0.030^{\mathrm{d}}$ \\
Alanine & $0.397 \pm 0.021^{\mathrm{a}}$ & $0.490 \pm 0.017^{\mathrm{bc}}$ & $0.420 \pm 0.030^{\mathrm{ab}}$ & $0.550 \pm 0.050^{\mathrm{c}}$ \\
Histidine & $2.023 \pm 0.084^{\mathrm{a}}$ & $1.823 \pm 0.025^{\mathrm{b}}$ & $2.240 \pm 0.040^{\mathrm{a}}$ & $1.870 \pm 0.010^{\mathrm{c}}$ \\
Tyrosine & $0.383 \pm 0.015^{\mathrm{a}}$ & $0.473 \pm 0.012^{\mathrm{b}}$ & $0.440 \pm 0.020^{\mathrm{ab}}$ & $0.550 \pm 0.040^{\mathrm{c}}$ \\
Arginine & $0.407 \pm 0.015^{\mathrm{a}}$ & $0.520 \pm 0.026^{\mathrm{bc}}$ & $0.470 \pm 0.010^{\mathrm{ab}}$ & $0.580 \pm 0.040^{\mathrm{c}}$ \\
EA/NEA & 0.25 & 0.33 & 0.27 & 0.34 \\
\hline
\end{tabular}

Data are expressed as mean \pm SD. Different letters within a row denote significant differences $(p<0.05)$. 
Amino acids are the building blocks of proteins that act as body builders. The cellular structure and function of body is largely depend on amino acids as it is serve as a source of energy (Babsky et al. 1989). Fish protein contains all the ten EAs in desirable quantity for human consumption. Unlike mammalian protein, fish protein is particularly rich in methionine and lysine, and low in tryptophan (Nowsad, 2007).

Nurullah et al. (2003) reported that the amount of glutamic acid in fish muscle was quite high while the other amino acids were slightly low. Similarly, Iwasaki and Harada (1985) have stated that the aspartic acid, glutamic acid, and lysine are the primary amino acids in fish muscles. In the present study, the ratio of EA/NEA amino acids were observed 0.25 and 0.27 in wild Koi fish collected in two different period as pre-monsoon and post-monsoon. Moreover the ratios were 0.33 and 0.34 in cultured fish during pre-monsoon and postmonsoon, respectively. Our finding indicated that that cultured Koi fish have a well-balanced and high-quality protein in the respect of EA/NEA ratio in postmonsoon.

Fatty acids profile: Fatty acids are mainly two types- Saturated Fatty Acid (SFA) and Unsaturated Fatty Acid (UFA). The total SFA content of lipids were $40.119 \%$ and $39.865 \%$ in wild Koi during pre-monsoon, while $39.748 \%$ and $37.573 \%$ in cultured Koi during post-monsoon, respectively. Wild A. testudineus contained58.674\% and $60.029 \%$ UFA in pre-monsoon and post-monsoon, respectively. In addition, the amount of UFA in both season were $60.114 \%$ and $61.322 \%$ in cultured fish.

Saturated Fatty Acid (SFA): The primary SFA was palmitic acid (C16:0). Result showed that wild Koi fish contained $29.377 \pm 0.003 \%$ and $27.138 \pm 0.002 \%$ palmitic acid in pre-monsoon and post-monsoon while the cultured Koi fish contained $30.277 \pm 0.255 \%$ and $27.359 \pm 0.007 \%$ in pre-monsoon and postmonsoon, respectively (Table 4). Data also expressed that significant variation $(p<0.05)$ was observed between wild fish of both seasons as well as cultured fish of both season. Stearic acid (C18:0) is also a major SFA. Amount of stearic acid in wild fishes in pre-monsoon and post-monsoon were $8.550 \pm 0.02 \%$ and $8.245 \pm 0.001 \%$, respectively. On the other hand, cultured fish contained $8.013 \pm 0.015 \%$ in pre-monsoon and $8.473 \pm 0.006 \%$ in post-monsoon. The amount of stearic acid varied significantly $(p<0.05)$ between wild and cultured fish of both seasons. Capric acid (C10:0) is present in both wild and cultured fish but the amount is minor. Among other SFA, caproic acid (C6:0), enanthic acid $(\mathrm{C} 7: 0)$, caprylic acid (C8:0) were not detected (ND) in cultured fish in premonsoon but present in wild fish. Lauric acid (C12:0), pentad cyclic acid (C15:0), arachidic acid (C20:0) were not detected in cultured fish in both 
seasons. Behenic acid (C22:0) and margaric acid (C17:0) were not detected in cultured fish as well as wild fish in pre-monsoon, but only present in wild fish during post-monsoon and the amounts were $0.072 \pm 0.001$ and $0.128 \pm 0.001$, respectively.

Unsaturated Fatty Acids: Monounsaturated Fatty Acids (MUFAs):Amount of oleic acid (C18:1) were $44.067 \pm 0.002 \%$ and $42.351 \pm 0.008 \%$ in wild and cultured fish during pre-monsoon, respectively; on the contrary, in post-monsoon, the amount were $32.764 \pm 0.18 \%$ and $44.994 \pm 0.007 \%$, respectively. Palmitoleic acid (C16:1) and Eicosenoic acid (C20:1) were present in both wild and cultured fish. The amount of almitoleic acid (C16:1) in wild A. testudineus were $4.782 \pm 0.001 \%$ and $4.616 \pm 0.007 \%$ in pre-monsoon and post-monsoon season, respectively whereas in cultured fish, the amount were $2.707 \pm 0.009 \%$ and $1.609 \pm 0.052 \%$, respectively.

Polyunsaturated Fatty Acids (PUFAs): In wild Koi, the amount of linoleic acid (C18:2) were $4.384 \pm 0.005 \%$ and $10.704 \pm 0.011 \%$ during pre-monsoon and postmonsoon, respectively. Conversely, cultured Koi fish contained $11.923 \pm 0.004 \%$ linoleic acid in pre-monsoon and $10.028 \pm 0.003 \%$ in post-monsoon. Significant variations $(p<0.05)$ existed in wild and cultured Koi between pre-monsoon and post-monsoon.

Cultured A. testudineus contained $0.396 \pm 0.007 \%$ and $0.583 \pm 0.025 \%$ eicosatrienoic acid (C20:3) in pre-monsoon and post-monsoon, whereas in the case of wild fish, the amount were $0.322 \pm 0.001 \%$ and $0.527 \pm 0.003 \%$, respectively. In wild fishes, amounts of linolenic acid (C18:3) were $1.613 \pm 0.009 \%$ and $3.567 \pm 0.008 \%$ in pre-monsoon and post-monsoon, respectively. In contrast, cultured Koi fish contained $0.825 \pm 0.006 \%$ linolenic acid in pre-monsoon and $1.383 \pm 0.003 \%$ in post-monsoon. The amount of arachidonic acid (C20:4) in wild Koi fish were $1.238 \pm 0.002 \%$ and $2.173 \pm 0.06 \%$ in pre-monsoon and postmonsoon, respectively; on the contrary, the amounts were $0.646 \pm 0.001 \%$ and $1.195 \pm 0.055 \%$ in cultured Koi fish. Amounts of eicosapentaenoic acid (EPA) (C20:5) in wild fish were $0.062 \pm 0.000 \%$ and $0.162 \pm 0.001 \%$ in pre-monsoon and post-monsoon, respectively; whereas EPA was not detected in cultured fish during pre-monsoon but in post-monsoon, EPA was detected and the amount was $0.329 \pm 0.001 \%$.

Hexadecadienoic acid (C16:2) and hexadecatrienoic acid (HTA) (C16:0) were absent in cultured Koi of both seasons, but present in the wild Koi. Docosatrienoic acid (C22:3) and adrinic acid (C22:4) were not detected in cultured fish during pre-monsoon. In contrast, these two polyunsaturated fatty acids were present in cultured Koi during post-monsoon and in wild fish during 
Table 4: Saturated and unsaturated fatty acid composition (\%) of wild and cultured $A$. testudineus in two different seasons

\begin{tabular}{|c|c|c|c|c|}
\hline \multirow[t]{2}{*}{ Fatty acids } & \multicolumn{2}{|c|}{ Pre-monsoon } & \multicolumn{2}{|c|}{ Post-monsoon } \\
\hline & Wild & Cultured & Wild & Cultured \\
\hline \multicolumn{5}{|c|}{ Saturated Fatty Acids (SFAs) } \\
\hline Caproic acid (C6:0) & $0.077 \pm 0.002^{\mathrm{a}}$ & ND & $0.673 \pm 0.003^{b}$ & $0.181 \pm 0.002^{c}$ \\
\hline $\begin{array}{l}\text { Enanthic acid } \\
\text { (C7:0) }\end{array}$ & $0.075 \pm 0.004^{a}$ & ND & $0.611 \pm 0.003^{b}$ & $0.345 \pm 0.001^{c}$ \\
\hline Caprylic acid (C8:0) & $0.058 \pm 0.001^{\mathrm{a}}$ & ND & $0.440 \pm 0.040^{\mathrm{b}}$ & $0.228 \pm 0.009 c$ \\
\hline Capric acid (C10:0) & $0.018 \pm 0.002^{\mathrm{a}}$ & $0.051 \pm 0.001^{\mathrm{c}}$ & $0.192 \pm 0.004^{b}$ & $0.133 \pm 0.007^{\mathrm{d}}$ \\
\hline Lauric acid (C12:0) & $0.054 \pm 0.003^{a}$ & ND & $0.176 \pm 0.001^{\mathrm{b}}$ & ND \\
\hline $\begin{array}{l}\text { Myristic acid } \\
(\mathrm{C} 14: 0)\end{array}$ & $1.630 \pm 0.020^{\mathrm{a}}$ & $1.524 \pm 0.006^{c}$ & $1.595 \pm 0.004^{\mathrm{b}}$ & $0.854 \pm 0.005^{\mathrm{d}}$ \\
\hline $\begin{array}{l}\text { Pentadecyclic acid } \\
\text { (C15:0) }\end{array}$ & $0.082 \pm 0.001^{\mathrm{a}}$ & ND & $0.252 \pm 0.001^{\mathrm{b}}$ & ND \\
\hline $\begin{array}{l}\text { Palmitic acid } \\
(\mathrm{C} 16: 0)\end{array}$ & $29.377 \pm 0.003^{a}$ & $30.277 \pm 0.255^{c}$ & $27.138 \pm 0.002^{\mathrm{b}}$ & $27.359 \pm 0.007^{\mathrm{b}}$ \\
\hline Stearic acid (C18:0) & $8.550 \pm 0.020^{a}$ & $8.013 \pm 0.015^{c}$ & $8.245 \pm 0.001^{\mathrm{b}}$ & $8.473 \pm 0.006^{\mathrm{d}}$ \\
\hline $\begin{array}{l}\text { Arachidic acid } \\
(\mathrm{C} 20: 0)\end{array}$ & $0.198 \pm 0.001^{\mathrm{a}}$ & ND & $0.226 \pm 0.003^{b}$ & ND \\
\hline $\begin{array}{l}\text { Behenic acid } \\
\text { (C22:0) }\end{array}$ & ND & ND & $0.072 \pm 0.001$ & ND \\
\hline $\begin{array}{l}\text { Margaric acid } \\
(\mathrm{C} 17: 0)\end{array}$ & ND & ND & $0.128 \pm 0.001$ & ND \\
\hline$\Sigma$ SFAs & 40.119 & 39.865 & 39.748 & 37.573 \\
\hline \multicolumn{5}{|c|}{ Unsaturated Fatty Acids (UFAs) } \\
\hline \multicolumn{5}{|c|}{ Monounsaturated Fatty Acids (MUFAs) } \\
\hline $\begin{array}{l}\text { Palmitoleic acid } \\
\text { (C16:1) }\end{array}$ & $4.782 \pm 0.001^{\mathrm{a}}$ & $2.707 \pm 0.009 \mathrm{c}$ & $4.616 \pm 0.007^{b}$ & $1.609 \pm 0.052^{\mathrm{d}}$ \\
\hline Oleic acid (C18:1) & $44.067 \pm 0.002^{\mathrm{a}}$ & $42.351 \pm 0.008^{c}$ & $32.764 \pm 0.180^{\mathrm{b}}$ & $44.994 \pm 0.007^{\mathrm{d}}$ \\
\hline $\begin{array}{l}\text { Eicosenoic acid } \\
(\mathrm{C} 20: 1)\end{array}$ & $0.747 \pm 0.003^{\mathrm{a}}$ & $0.281 \pm 0.002^{c}$ & $0.857 \pm 0.003^{\mathrm{b}}$ & $0.435 \pm 0.003^{\mathrm{d}}$ \\
\hline$\Sigma$ MUFAs & 49.596 & 45.339 & 38.237 & 47.038 \\
\hline \multicolumn{5}{|c|}{ Polyunsaturated Fatty Acids (PUFAs) } \\
\hline $\begin{array}{l}\text { Hexadecatrienoic } \\
\text { acid }(\mathrm{C} 16: 0)\end{array}$ & $0.133 \pm 0.001^{\mathrm{a}}$ & ND & $0.744 \pm 0.003^{\mathrm{b}}$ & ND \\
\hline $\begin{array}{l}\text { Hexadecadienoic } \\
\text { acid (C16:2) }\end{array}$ & $0.103 \pm 0.006^{a}$ & ND & $0.503 \pm 0.006^{b}$ & ND \\
\hline Linoleic acid (C18:2) & $4.384 \pm 0.005^{\mathrm{a}}$ & $11.923 \pm 0.004^{c}$ & $10.704 \pm 0.011^{\mathrm{b}}$ & $10.028 \pm 0.003^{\mathrm{d}}$ \\
\hline $\begin{array}{l}\text { Linolenic acid } \\
\text { (C18:3) }\end{array}$ & 1. $613 \pm 0.009^{a}$ & $0.825 \pm 0.006^{c}$ & $3.567 \pm 0.015^{b}$ & $1.383 \pm 0.003^{\mathrm{d}}$ \\
\hline $\begin{array}{l}\text { Eicosadienoic acid } \\
\text { (C20:2) }\end{array}$ & $0.321 \pm 0.003^{a}$ & ND & $0.466 \pm 0.001^{\mathrm{b}}$ & ND \\
\hline $\begin{array}{l}\text { Eicosatrienoic acid } \\
\text { (C20:3) }\end{array}$ & $0.322 \pm 0.001^{\mathrm{a}}$ & $0.396 \pm 0.007^{c}$ & $0.527 \pm 0.003^{b}$ & $0.583 \pm 0.025^{d}$ \\
\hline $\begin{array}{l}\text { Arachidonic acid } \\
\text { (C20:4) }\end{array}$ & $1.238 \pm 0.002^{\mathrm{a}}$ & $0.646 \pm 0.001^{c}$ & $2.173 \pm 0.060^{\mathrm{b}}$ & $1.195 \pm 0.055^{\mathrm{b}}$ \\
\hline $\begin{array}{l}\text { Eicosapentaenoic } \\
\text { acid (C20:5) }\end{array}$ & $0.062 \pm 0.001^{\mathrm{a}}$ & ND & $0.162 \pm 0.001^{\mathrm{b}}$ & $0.329 \pm 0.002^{c}$ \\
\hline $\begin{array}{l}\text { Docosatrienoic acid } \\
\text { (C22:3) }\end{array}$ & $0.444 \pm 0.006^{\mathrm{a}}$ & ND & $0.621 \pm 0.003^{b}$ & $0.257 \pm 0.004^{c}$ \\
\hline Adrinic acid (C22:4) & $0.344 \pm 0.003^{a}$ & ND & $0.335 \pm 0.011^{\mathrm{a}}$ & $0.371 \pm 0.000^{\mathrm{b}}$ \\
\hline $\begin{array}{l}\text { Docosapentanoic } \\
\text { acid (C22:5) }\end{array}$ & $0.756 \pm 0.007^{a}$ & $0.014 \pm 0.001^{\mathrm{c}}$ & $0.582 \pm 0.011^{\mathrm{b}}$ & ND \\
\hline $\begin{array}{l}\text { Docosahexaenoicaci } \\
\text { d (C22:6) }\end{array}$ & $0.971 \pm 0.006^{a}$ & $0.971 \pm 0.001^{\mathrm{b}}$ & $1.408 \pm 0.018^{\mathrm{b}}$ & $0.138 \pm 0.000^{c}$ \\
\hline$\Sigma$ PUFAs & 9.078 & 14.775 & 21.792 & 14.284 \\
\hline$n-3 / n-6$ & 0.35 & 0.14 & 0.48 & 0.17 \\
\hline
\end{tabular}


both seasons. Docosapentanoic acid (DPA) (C22:5) was not detected in cultured fish in post-monsoon but present in pre-monsoon cultured fish. Eicosadienoic acid (C20:2) was not found in cultured fish but present in wild Koi fishes. In premonsoon, ratio of $\mathrm{n}-3 / \mathrm{n}$-6were 0.35 and 0.14 for wild and cultured Koi fish, Values in the same row having the different superscript are significantly respectively whereas in post-monsoon these ratios were 0.48 and 0.17 , respectively. Different $(p<0.05)$

Our analysis suggested that wild Koi fish are nutritionally superior to the cultured Koi fish in terms of fatty acid content. In particular, PUFAs were predominant in wild Koi while MUFAs were dominant in cultured Koi fish.

Stansby (1982) documented palmitic acid (C16:0) as the prevalent SFA, which accounted for $20-50 \%$ of total fatty acid in some fish lipids. Similarly, we found palmitic was dominant in both the farmed and wild Koi fish, contributing approximately $70 \%$ to the total SFA content irrespective of both seasons (premonsoon and post-monsoon).

Proportions of saturated fatty acids (C14:0, C16:0, C18:0, C20:0) varied irregularly in lipids of the liver from both wild and cultured Gibelion catlafish (Hassan et al., 2010).Oleic acid (C18:1) was contained in large quantities in the liver of wild as well as cultured G. catla, while linolenic acid (C18:3) and eicosadienic acid (C20:2) were detected only in the liver of wild G. catla. These findings were corroborated with our findings of higher concentration of PUFA in wild Koi than in cultured Koi.

In relation to the relative nutritional values of fish oil of various species, Piggott and Tucker (1990) proposed the $n-3 / n-6$ ratio is a better quality measure. Therefore, it would be better to consume fish that have a high ratio of $\mathrm{n}-3 / \mathrm{n}-6$. In pre-monsoon, wild and cultured fish amount of $n-3 / n-6$ ratio is 0.35 and 0.14 whereas in post-monsoon the amount was 0.48 and 0.17 , respectively.

\section{CONCLUSION}

Findings of the study showed seasonal variations in proximate, fatty acid and amino acid profile of wild and cultured A. testudineus. Generally, cultured fish are supplemented with nutrient-rich foods and the supplemented food is mainly rich in animal protein. As a result cultured fish contain more protein than wild. This amount is also varying based on season may be due to the change in water quality and other parameters of the environment. But more research is needed to draw a conclusion regarding these findings. 


\section{LITERATURE CITED}

ALAM, A.K.M.N. 2007. Participatory Training of Trainers: A new approach applied in Fish Processing. Bangladesh Fisheries Research Forum. 329 pp.

ALEMU, L.A., MELECE, A.Y. and GULELAT, D.H. 2013. Effect of endogenous factors on proximate composition of Nile tilapia (Oreochromis niloticus L.) fillet from Lake Zeway. Am. J. Res.Commun. 1(11): 405-410.

ANONYMOUS. 1993. Amino acid analysis system instruction manual. Shimadzu HPLC amino acid analysis system. Shimadzu Corporation, Analytical Instruments Division, Kyoto, Japan, pp. 63-65.

AOAC. 1995. Official Methods of Analysis of AOAC International. 16th ed. Association of Official Analytical Chemists. Arlington, VA, USA.

BABSKY, E.B., KHODOROV, B.I., KOSITSKY, G.I. and ZUBKOV, A.A. 1989. Human Physiology, Vol. 2. MIR Publishers, Moscow.

BELTON, G.S., REINE, W.F., HUISMAN, J.M., DRAISMA, S.G., GURGEL, D. and FREDERICO, C. 2014. Resolving phenotypic plasticity and species designation in the morphologically challenging Caulerparacemosa-peltata complex (Chlorophyta, Caulerpaceae). J. Phycol. 50(1): 32-54.

CELIK, M., DILER, A. and KUCUKGULMEZ, A. 2005. A comparison of the proximate compositions and fatty acid profiles of zander (Sander lucioperca) from two different regions and climatic conditions. Food Chemistry 92(4): 637-641

DoF. 2015. National fish week 2015 Compendium (in Bangla). Department of Fisheries, Ministry of Fisheries and Livestock, Bangladesh. 148 pp.

EXLER, J., KINSELLA, J.E. and WATT, B.K. 1975. Lipids and fatty acids of important finfish: new data for nutrient tables.J.Am. Oil Chem. Soc. 52(5): 154-159.

FAO. 1991. Wholesomeness of irradiate food. Report of a joint FAO/IAEA/WHO experts committee. WHO. Tech. Report Series. 659: 7-34

FAO. 2018. The State of World Fisheries and Aquaculture 2018 - Meeting the sustainable development goals. Rome. xvi $+211 \mathrm{pp}$.

FOLCH, J.B. and STANLY, G.H. 1957. A sample method for the isolation and purification total lipids from animal tissue. J. Biol. Chem. 226: 697-709

FRSS. 2015. Fisheries Statistical Report of Bangladesh. Fisheries Resources Survey System (FRSS), Department of Fisheries, Bangladesh. Volume 31: 57

HASSAN, M., CHATHA, S.A.S., TAHIRA, I. and HUSSAIN, B. 2010. Total lipids and fatty acid profile in the liver of wild and farmed Catla catla fish. Grasas Y Aceites. 61(1): 52-57.

HOSSAIN, M.N., AFROZ, H., HAQUE, M.Z. and BEGUM, M. 2015. Evaluation of nutritional properties of some small indigenous fish species in Bangladesh. Bangladesh J. Zool. 6(6): 102-109. 
HUSS, H.H. 1995. Quality and quality changes in fresh fish. FAO fisheries technical paper. 348, 195 pp.

IWASAKI, M. and HARADA, R. 1985. Proximate and amino acid composition of the roe and muscle of selected marine species. J. Food Sci. 50(6): 1585-1587.

LI, G., SINCLAIR, A.J. and LI, D. 2011. Comparison of lipid content and fatty acid composition in the edible meat of wild and cultured freshwater and marine fish and shrimps from China. $J$. Agricult. Food Chem. 59 (5): 1871-1881

MAZUMDER, M.S.A., RAHMAN, M.M., AHMED, A.T.A., BEGUM, M. and HOSSAIN, M.A. 2008. Proximate composition of some small indigenous fish species (SIS) in Bangladesh. Int. J. Sust. Crop Pro. 3(4): 18-23.

MURRAY, J. and BURT, J.R. 2001. The Composition of Fish. Torry advisory note no. 38. Ministry of Technology, Torry Research Station. $13 \mathrm{pp}$.

NICHOLS, D.S., NICHOLS, P.D. and MCMEEKIN, T.A. 1993. Polyunsaturated fatty acids in Antarctic bacteria. Antarct. Sci. 5(2): 149-160.

NURUllAH, M., KAMAL, M., WAHAB, M.A., ISLAM, M.N., AHASAN, C.T. and THILSTED, S. 2003. Nutritional qualities of some small indigenous fish species of Bangladesh. In Proceedings of BAU-ENRECA/DANIDA Workshop on Small Indigenous Species of Fish (SIS) in Aquaculture $\&$ Rice-field Stocking for Improved Food \& Nutrition Security in Bangladesh. 30-31 October 2002, Bangladesh and ENRECA/DANIDA, pp. 151-158.

ONYIA, L.U., MICHAEL, K.S., MANU, J.M. and SABO, M. 2013. Comparison of Nutrient Values of Wild and Cultured Heterobranchusbidorsalis and Clarias gariepinus. Nigerian J. Fish. Aquacult. 1(1): $7-12$.

PIGOTT, G.M. and TUCKER, B.W. 1990. Sea Food: Effects of Technology on Nutrition. CRC Press, Marcel Dekker Inc. New York, 384 pp.

PUWASTIEN, P., RAROENGWICHIT, M., SUNGPUAG, P. and JUDPRASONG, K. 1999. Thai food composition tables. Institute of Nutrition, Mahidol University (INMU), Thailand, $150 \mathrm{pp}$.

SHEARER, K.D. 1994. Factors affecting the proximate composition of cultured fishes with emphasis on salmonids. Aquaculture 119(1): 63-88.

STANSBY, M.E. 1982. Properties of fish oils and their application to handling of fish and to nutritional and industrial use. In: Chemistry and biochemistry of marine food products (Ed., Martin, R.E., Flick, G.J., Hebard, C.E. and Ward, D.R.) Avi Publishing Wesport, Connecticut, pp. 75-92

YEGANEH, S., SHABANPOUR, B., HOSSEINI, H., IMANPOUR, M.R. and SHABANI, A. 2012. Comparison of farmed and wild common carp (Cyprinus carpio): seasonal variations in chemical composition and fatty acid profile. Czech J. Food Sci. 30(6): 503-511.

(Manuscript received on 15 May, 2020 revised on 20 September, 2020) 